\title{
Aesthetic Learning by Implementing Systemic Approach to Achieve Educationional Values in Performing Arts
}

\author{
Dwi Kusumawardani ${ }^{\bowtie}$ \\ Department of Dance Education, Faculty Languages and Arts, \\ Universitas Negeri Jakarta, Indonesia
}

Submitted: August 10, 2019. Revised: November 4, 2019. Accepted: December 28, 2019

\begin{abstract}
This study is aiming at developing aesthetic learning design with a systemic approach to achieve educational value in performing arts. The study was conducted by employing research \& development approach, consisting of stages, i.e. (1) identifying learning objectives, preceding by need assessments, (2) doing learning analysis, (3) analyzing students' behavior and characteristics, (4) identifying specific learning objectives, (5) developing learning outcomes assessment tool, (6) developing learning strategy, (7) selecting and developing learning material, (8) designing and evaluating formative learning design, and (9) designing and conducting summative evaluations. The results of this study are a set of aesthetic learning implementation plan with a systemic approach that meets the development criteria. The aesthetic learning design has been tested and tried out; and is effectively able to achieve the learning objectives of the aesthetic course in university; namely, students are able to find the value of education in performing arts and foster aesthetic sensitivity.
\end{abstract}

Keywords: Educational Value; Performing Arts; Learning Design; Systemic Approach

How to Cite: Kusumawardani, D. (2019). Aesthetic Learning by Implementing Systemic Approach to Achieve Educationional Values in Performing Arts. Harmonia: Journal of Arts Research And Education, 19(2), $126-132$.

\section{INTRODUCTION}

The educational value is the quality of an object that educates a person to behave well and be beneficial for life. Educational value can be obtained through various means, including learning from others, learning from one's own experience, observing events, or from the artwork. The value of education in art can be found through the activity of interpreting symbols contained in art elements (Sofyan, et al., 2017). The activity of interpreting art symbols is one of the activities to appreciate art. Activities appreciate art, including observing art, interpreting symbols in art, discovering values in art, and valuing art. As a result of these activities, a person will be able to enjoy art and have an attitude of being able to appreciate art (Barrett, 1994).

Human as animal symbolicum (Cassirer, 1992) communicates messages to others not only with language but also with other symbols. The symbol comes from the Greek word, symbols in the Latin word symbolism, and icon in the Indonesian language (KBBI). A symbol is a tool used to tell others. Symbols in the performing arts can be actions, artistic events, atmosphere, movements, words, storylines, sounds, colors, properties, or costumes used to

Corresponding author:

E-mail: dwikusumawardani@unj.ac.id 
convey the purpose/ meaning of the performing arts. Human actions that reflect the life or philosophy of society are called symbolic actions (Sachari, 2002).

Symbols are also found in art elements. Art elements include art structure, theme, medium, and art style (Gie, 1976). Some elements of art are in concrete form and some are abstract. Medium and style include in concrete forms because they can be seen and heard. The theme (subject matter) is abstract, because the meaning is known after being interpreted. The elements of art are usually associated with values in art, one of which is the value of education.

Various values in the performing arts include the values of knowledge, religious values, moral values, social values, and human values (Anoegrajekti, 2008). The value of knowledge is a quality inherent in the performing arts. Useful to explain natural knowledge, social-humanities knowledge, technology, culture, and art. Religious value is a quality inherent in the performing arts, to awaken a person, to obey, and practice the teachings of each other's faith or religion. Moral value is a quality inherent in the art of performance, to awaken one to do good according to prevailing life norms. Social value is a quality inherent in the performing arts for one to behave in harmony with the community or other people. Humanity values, in addition, are qualities inherent in the performing arts, so one is respecting and caring for the right to life or human rights of others - for example, the attitude of helping others, love, peace, tolerance, democracy, and cooperation.

The attitude of appreciating works of art is one of the good behaviors that need to be developed in a person so that someone becomes a complete human being. It is a man who is not only intellectually intelligent but also physically and mentally healthy, besides having a noble character. Noble character, moreover, is shown from the behavior of someone who wants to practice the good teachings of his religion, has good ethics, has a good social attitude, has a caring attitude, and can respect others (Sa'dullah, 2016).

The results of preliminary studies on the implementation of aesthetic learning show the dominant learning activities the classroom is about Aesthetic knowledge. Learning interactions occur in one direction because lecturers dominate the learning process, and students look passive. Assessment is done in writing only for measuring students' mastery of aesthetic concepts. Student learning resources are limited to printed media (books) and videos which are resulted in less than optimal learning outcomes.

Aesthetic learning outcomes should be directed to the realm of attitude, i.e., students are able to find the values of art, students have aesthetic sensitivity, and students can appreciate the work of others. The assessment process is supposed to not only measure the ability through written tests since it limits students' ability to think about aesthetic concepts and principles.

In order to produce effective and efficient learning to achieve aesthetic learning goals, it is necessary to apply the learning design procedures sequentially. Therefore, in this research an aesthetic learning design will be developed that integrates all learning components including varied learning objectives, processes, and learning resources.

\section{METHOD}

Aesthetic learning design in research uses research and development approaches. This approach follows the stages including (1) identifying learning objectives (2) conducting learning analysis (3) analyzing learners and context (4) writing performance goals (5) developing assessment instruments (6) developing learning strategies (7) developing and selecting teaching materials, and (8) designing and conducting formative evaluations of teaching, and (9) designing and conducting summative evaluations (Dick, et al., 2009).

The nine stages are written basically cover three main activities, namely preli- 
minary research, learning development, and the final research. The initial stage conducted was the activity of analyzing the need to obtain data about the gap between learning what currently occurs and what needs to happen. Here, the research was carried out by qualitative methods. Meanwhile, the data was collected through observation and interview techniques. The observation was done to obtain data about the process and learning outcomes of the aesthetic course. The data obtained was further clarified to lecturers and students using interviews. At the learning development stage, research activities were carried out to develop aesthetic learning design with systemic approach that includes: (1) formulation of general objectives of aesthetic learning (learning achievements in aesthetic subjects), (2) competency mapping of aesthetic subjects, (3) behavioral data and characteristics students, (4) formulation of special learning objectives (sub-learning achievement of aesthetic subjects), (5) learning outcome assessment instruments, (6) learning strategies, and (7) teaching materials. Formative evaluation is carried out with the aim of obtaining feedback from experts, lecturers and students. The data collection techniques used include expert reviews, one-to-one evaluations to three students individually, small group evaluations to 8-12 students, and field trial to approximately 30 students. The data obtained were analyzed qualitatively and quantitatively.

Information obtained from formative evaluation activities were used as the basis for improving the aesthetic learning design developed. Meanwhile, summative evaluation in this study was not conducted because the summative evaluation was not part of the learning design development process. And, the summative evaluation in this study was not carried out because the tes is an assessment of the results of the dissemination of learning products on a broad scale known as the process of innovation diffusion.

\section{RESULTS AND DISCUSSION}

\section{Aesthetic Learning with Systemic Ap- proach}

Aesthetic learning with a systemic approach was developed to improve student learning outcomes. Through this approach, it is expected that students' thinking abilities develop, so they are able to find the values contained in the performing art. In addition, through this approach, it is also hoped that a nurturant effect is obtained, which is the aesthetic sensitivity of students when watching a performing art. The nurturant effect in learning is the learning outcomes obtained by students from an atmosphere that is experienced directly and is not specifically directed by the lecturer (Joyce, et al., 1980).

Aesthetic learning with the systemic approach model developed in this study consists of a unity of learning components that can be used effectively to achieve the aesthetic learning goals. The unity of these components, summarized in the Semester Learning Plan and aesthetic course learning materials. The aesthetic learning design component developed in this study has several characteristics, as follows:

Aiming at achieving learning outcomes in the affective domain; here, students have aesthetic sensitivity well, after being asked to find the educational value of symbols in the elements of the performing arts;

Indicators of aesthetic sensitivity learning outcomes comprise the ability to: (1) explain the concepts and principles of aesthetic performances, (2) describe the performing art that is observed chronologically and comprehensively, (3) interpret symbols from the elements of the observed performing art, (4) find values in the performing arts that are observed, and (5) accept the educational value of the elements of the performing arts. Acceptance of values is an indicator of effective ability. Acceptance of values is at the lowest level when one believes in the educational values contained in the performing arts and the highest level if one has a commitment 
to these values (Krathwohl, et al., 2009). In this context, it is when students have already had a commitment to the values contained in the elements of the performing arts, which means that students already have aesthetic sensitivity. Aesthetic sensitivity is the ability for a person to feel and enjoy art because of his acceptance of the values of art symbols so that he can appreciate the work of others.

Learning material, consisting of (1) basic aesthetic concepts, covering sub-topics: understanding aesthetics, aims and benefits of aesthetics studied, aesthetic values, and aesthetic experiences, art, and artists, and (2) aesthetic performing arts, including sub-subjects: understanding dance/ music/ theater, dance/ music/ theater elements as sources of beauty, aesthetic values in dance/ music/ theater, dance/ music/ theater beauty criteria, and dance/ music/ theater aesthetic studies;

The stages of learning were begun with preliminary activities, core activities, and closing activities.

The preliminary activity stage, the lecturer, conducts orientation, apperception, explains the purpose, benefits, and relevance of the topic being studied explains the mechanism of learning implementation.

The core activity stage, three different learning types were conducted in sequence, comprising: (1) Concept presentation. The basic concept of aesthetics is presented using lecturing method, and questions and answers by lecturers at meetings 1-2. In the meetings 3-8 group presentation by students is conducted; (2) analysis of thinking ability, that is, students are asked to express their thoughts and discuss various thoughts related to the subject matter that has been presented by each group of students. The method applied is the method of discussion in groups, and the method of brainstorming with other groups in the class; (3) concept testing, where students are asked to give examples or be given tests relating to the learning material pre- sented; (4) observation, it is when students are asked to observe the art of performance and its elements from audio-visual media or reality media (art performances). Both of these media have advantages to provide a concrete learning experience for students (Heinich, 1996); (5) interpreting, it is when students are asked to interpret the meaning of the symbols that are in the elements of the performing arts; (6) assessing, it is when students are asked to rate the performing arts based on size or criteria of beauty formation and content. The closing activity stage, the lecturer concludes, gives feedback, conveys follow-up, and provides information for next meeting material.

\section{Effectiveness of Aesthetic Learning with Systemic Approach}

Based on the results of the teaching model try out, we can see that the application of aesthetic learning design has a positive impact on student learning outcomes. This can be seen from the comparison of the acquisition of student grades before and after applying aesthetic learning with a systemic approach. A comparison of the value of the results of the pretest and posttest is explained in the following table (Table 1).

Based on the data in Table 1, most of the student learning outcomes improve after participating in aesthetic learning with a systemic approach. Although the increase in grades for each student varies greatly. More detailed information is described as Table 2.

Based on the data in Table 2, the increase in the value of student learning outcomes at the time of the pre-test and posttest are (1) the average grade of the class which was originally 29.58 increased to 71.08; (2) the median value was increased from 30 to 72 ; (3) the mode value of 0 increased to 84 ; $(4)$ the highest minimum value, which originally was 0 , increased to 51; and (5) the original maximum value of 80 increased to 87. 
Table 1. Comparison of Pre-test and Post Test

\begin{tabular}{|c|c|c|}
\hline \multirow{3}{*}{ Student } & \multicolumn{2}{|l|}{ Scoring } \\
\hline & \multicolumn{2}{|c|}{ Score } \\
\hline & Pre-test & Post Test \\
\hline 1 & 60 & 87 \\
\hline 2 & 0 & 84 \\
\hline 3 & 70 & 84 \\
\hline 4 & 60 & 84 \\
\hline 5 & 40 & 78 \\
\hline 6 & 80 & 78 \\
\hline 7 & 0 & 77 \\
\hline 8 & 40 & 75 \\
\hline 9 & 50 & 74 \\
\hline 10 & 60 & 74 \\
\hline 11 & 30 & 73 \\
\hline 12 & 0 & 72 \\
\hline 13 & 40 & 72 \\
\hline 14 & 0 & 69 \\
\hline 15 & 0 & 69 \\
\hline 16 & 20 & 67 \\
\hline 17 & 50 & 65 \\
\hline 18 & 30 & 65 \\
\hline 19 & 0 & 64 \\
\hline 20 & 0 & 63 \\
\hline 21 & 50 & 62 \\
\hline 22 & 0 & 60 \\
\hline 23 & 0 & 59 \\
\hline 24 & 30 & 51 \\
\hline
\end{tabular}

Table 2. The Score Improvement after the Implementation of Aesthetic Learning with Systemic Approach

\begin{tabular}{lcc}
\hline & Pre-Test & Post Test \\
\hline Mean & 29.58 & 71.08 \\
Median & 30 & 72 \\
Mode & 0 & 84 \\
Minimum & 0 & 51 \\
Maximum & 80 & 87 \\
\hline
\end{tabular}

The effectiveness of aesthetic learning designs developed is also demonstrated by the achievement of the score/mark of papers, group presentations, summary, and the final project done by students. The score of group papers discussing topics in aesthetic subjects obtained an average grade of 3.8 (good). The score of group presentations obtained an average value of 3.6 (good). The score of the assignment to make a summary of the material from meetings 1-7 obtained an average grade of 3.6 (good). While, the score of the final project to within the theme of aesthetic values in dance/ music/ theater, obtained an average value of 3.6 (good).

Based on the achievement of the learning outcomes, it can be interpreted that: (1) students master the basic aesthetic concepts well; (2) students master how to find values in the performing arts well; and (3) students are able to find values in the performing arts, to make a paper of aesthetic values in dance/ music/ theater comprehensively. These conditions can be interpreted that the learning system, which consists of a unity of aesthetic learning components arranged systematically and systemically, is effective in achieving the learning objectives of the aesthetic course.

Based on the results of the development, it can be concluded that the learning of aesthetic courses taking place during the tryout has the following advantages.

Developed based on the process of learning approach development with a systemic approach by experts in Educational Technology, which processes are complete. First, conducting the initial research (need assessment). Second, the development of learning is carried out, covering seven activities. Third, final research (formative evaluation) is carried out to ensure aspects that need to be improved so that the learning developed is effective, efficient, and attractive to students.

Developed with a systemic approach that is integrating learning sub-systems (competencies, materials, strategies, methods, media, assessments, learning resources) into a single unit according to their respective functions. The process of integrating the learning sub-system is done in sequence according to the instructional design model approach to the systemic approach;

It is effective in achieving the learning objectives of the aesthetic course in 
the affective domain.

It is efficient because it is in accordance with the sources had by the Study Program and the Faculty, comprising: (a) the lecturer carries out the material and masters the learning process, (b) the allocation of student learning time is designed for two credits, and is carried out in accordance with the credit system. The time allocated is 100 minutes face to face, 120 minutes for students to study independently, and 120 minutes for students to have structured learning, (c) varied learning media, and learning aids are available.

It is easy and interesting for students to learn because it is carried out with a variety of learning activities, various learning methods, and various learning resources. While based on observations during the implementation process, several important things can be explained as follows.

Its application requires adequate resources. Lecturers must have the skills to implement the learning system. Lecturers must master the subject matter, learning strategies, various learning methods, assessment techniques and various learning resources. If the lecturer does not have these skills. As a result, the aesthetic learning system cannot be implemented optimally; even the lecturers will have difficulty in implementing it.

Learning resources are not enough if only from printed media. Learning resources must be varied, and audio-visual learning media is a must. This is because the ultimate goal of learning is in the affective domain.

\section{CONCLUSION}

Good behavior, which is beneficial for life, is one of the goals of national education that shapes a person into a complete human being. Every human being has the right to become a complete human being, that is, to have spiritual intelligence, intellectual intelligence, physical and mental health, and good character. A person needs to be educated through learning to have this ability,
Aesthetic Learning, as one of the courses in the group of art education study program, aims to educate one to have good character or behavior. One way is by learning to find the value of knowledge, religion, moral, social, and humanity of the symbols in the elements of the performing arts. Performing arts elements, including actions and events of art, atmosphere, movement, sound, words, storyline, color, property, clothing, and other performing art elements, are interpreted to determine their educational values. The value of education is expected to be understood, realized, and carried out in daily life.

The success of the implementation of aesthetic learning can be measured from the achievements of learning outcomes. In the context of this study, it is evident that aesthetic learning with a systemic approach that is developed is capable and effective in achieving the stated learning objectives. Student learning outcomes in aesthetic learning based on the results of trials increased in terms of both achieving the average, median, mode, minimum, and maximum value.

In addition, it was also shown by the achievement of the value of other tasks within an average score of 3.6, which means that the criteria are good. This shows that the application of aesthetic learning designed based on a systemic approach has succeeded in achieving learning objectives. Aesthetic learning that takes place implements a variety of procedures for art appreciation activities, learning processes, and a variety of learning resources so that attractive to students. At the end of the lecture, students have good aesthetic sensitivity, after being asked to find educational values in the performing arts presented in the paper.

\section{REFERENCES}

Anoegrajekti, N. (2008). EstetikaSastra, Seni dan Budaya. Jakarta: Universitas Negeri Jakarta Press.

Barrett, T. (1994). Principles for Interpreting Art. Art Education, 47(5), 8-13. 
Cassirer, E. (1992). An Essay on Man: An Introduction to a Philosophy of Human Culture. New Haven: Yale University.

Dick, W. (2009). A model for the systematic design of instruction. Instructional Design: International Perspectives I: Volume I: Theory, Research, and Models: volume Ii: Solving Instructional Design Problems, 361.

Gie, T. L. (1976). Garis Besar estetika (Filsafat Keindahan). Jakarta: Pusat Ilmu Berguna.

Heinrich, R. (1996). Instructional Media end Technologies for Learning. New Jersey: Prentice-Hall.

Joyce, B. \& Weill, M. (1980). Models Of Teaching. New Jersey: Prentice-Hall.

Krathwohl, D. R., \& Anderson, L. W.
(2009). Toxonomy of Educational objektives. London: Longman Group, LTD.

Sa'dullah, M. (2016). Pembelajaran Aoresiasi Seni Musik Kelas VIIA SMP Negeri 1 Welahan. Semarang: Universitas Negeri Semarang

Sachari, A. (2002). Estetika: makna, simbol dan daya. Bandung Press.

Sofyan, A., \& Susetyo, B. (2017). Penanaman Nilai Karakter Melalui Pembelajaran Seni Musik di SMP Negeri 2 Semarang. Jurnal Seni Musik, 6(2), 1-8

Utomo, U., \& Sayuti, S. A. (2017). Developing an instrument model to assess teachers ' creativity in designing and teaching music subject. Harmonia: Journal of Arts Research and Education, 17(1), 13-22. 